CURRENT RESEARCH

\title{
RECENT SEDIMENTS
}

Sediments in Cardigan Bay and Rustico Harbour areas, P.E.I.

Recent sedimentary deposits in Cardigan Bay, a large land-locked east-facing natural harbour in eastern Prince Edward Island, were sampled in July 1966 by DR. DERYCK J.C. LAMING of the UNIVERSITY OF NEW BRUNSWICK. The area investigated included the drowned valleys of the Cardigan, Brundenell and Montague Rivers which merge to form the bay, and parts of the adjacent Northumberland Strait. Boughton and Panmure Islands, which flank the entrance of the bay, are joined to the land by tombolo spits, one of which is submerged at high tide; interesting comparisons are hoped for in these areas.

Over 160 samples were collected from the area, which measures 6 miles wide by 12 miles east-west overa11. Beach, backshore and surf-zone samples were included. For the marine work, the vessel used was CSL Tudlik, an efficient 37-foot fibreglass survey launch kindly loaned by BEDFORD INSTITUTE OF OCEANOGRAPHY. Samples were caught by using a Dietz-LaFond grab, and current measurements during the project were made using a Kelvin Hughes Direct Reading Current Meter. Dr. Laming was assisted by SANDRA BARR and FAYE MURRAY, also of U.N.B. The samples will be processed at U.N.B., and an attempt will be made to correlate the results with a computed model based on averaged wind strength, direction and fetch data for the bay.

In early August, Dr. Laming and party undertook another topographic and sedimentary survey of the Rustico Harbour area. Using a portable echo-sounder in a lobster boat, a depth survey of the rapidly-changing channels and bars of the area was made, followed by the collection of over 200 sediment samples; current measurements were made using home-made floats. This continues the series of surveys of topography and sediments made by JOHN $W$. ROWLING, Dr. Laming, and the Federal DEPARTMENT OF PUBLIC WORKS (reported in Maritime Sediments 1-iii 1, 2-i 32). The object of the study is to relate sedimentary textural parameters to environment and bedform in a rapidly changing situation, the changes resulting from alteration of tidal flow when a causeway was built across one exit from Rustico Bay eleven years ago. As the positions of bars change, so it may be possible to see whether the relationship of texture to environment is a valid one, or whether the textural parameters characterize sand bodies instead. An area of about $0.5 \mathrm{sq}$ miles is involved.

A smal1 island forming at the harbour mouth is the subject of special attention. Two years ago this was an intertidal feature subject to tide and wave action, but parts of it are now fully emergent and a check is being kept upon its development. Sedimentary processes and structures are being studied at a11 states of tide and in varying weather conditions, in the hope that more may be learned about the growth of barrier islands in adjacent North Shore areas of Prince Edward Island. 
Dr. Laming is also continuing work on sediments in the Alma area of Chignecto Bay, Bay of Fundy (Maritime Sediments, 2-i 3-5). He recently flew an air-photo mission over the area, and over the ParrsboroFive Islands area of Minas Basin in collaboration with HUDSON LABORATORIES OF COLUMBIA UNIVERSITY. It is intended to use a sparker in both areas in the near future to study both superficial sediments and bedrock discontinuities (Carboniferous) underwater.

These projects are being supported by grants from the GEOLOGICAL SURVEY OF CANADA.

Texture, colour, structures and dispersal of coastal and offshore sediments

In addition to co-ordinating several marine geology projects on the Scotian Shelf and slope and on the Bermuda Pedestal (Maritime Sediments, 2-ii 84-86, Apri1 1966), DR. DANIEL J. STANLEY of the DALHOUSIE INSTITUTE OF OCEANOGRAPHY is presently completing other sedimentological projects:

Statistical analysis of coastal sand deposits - Differences in sands collected in adjacent nearshore environments are slight and, at best, difficult to recognize. Few methods of analysis have proved to be truly reliable for distinguishing environments solely on the basis of the petrographic composition of samples. In an attempt to obtain a different approach to this problem and to see if the results could be applied as well to similar sediment types in the fossil record, a quantitative study of sands was initiated in the Black Beach-Sippewissett Marsh area of Cape Cod, Mass.

Over two hundred samples were collected along a grid pattern in a one-half square mile area comprising adjacent dune, beach, offshore bar, tidal delta and tidal channel environments. Nineteen textural and mineralogical parameters were calculated for each sample. Grain size was measured using the modified Woods Hole Rapid Sediment Analyzer at WOODS HOLE OCEANOGRAPHIC INSTITUTION and the similar one recently extablished at the Marine Geology Laboratory at DALHOUSIE UNIVERSITY. Light and heavy minerals were also examined. Surface textures of grain surfaces will be studied by electron microscopy.

These data are being processed by computer using a program formulated for this purpose by Mr. PETER BUTTNER of the Computer Center, UNIVERSITY OF ROCHESTER。 Preliminary results suggest that certain statistical computations combining moment measures and heavy mineral data can be used to distinguish coastal-nearshore environments. An attempt is being made to apply the same methods for interpreting the specific depositional environment of ancient sedimentary rocks.

Sediment dispersal patterns in the Northwest Arm, Halifax Harbour In order to interpret the origin of sediments and their dispersal in a small fjord environment, a sampiing program was initiated in the Northwest Arm near Halifax, Nova Scotia in the Fall of 1965 . Over 110 samples were collected in the linear body, which is $5 \mathrm{~km}$ long, about . $3 \mathrm{~km}$ wide and over 20 metres deep. Observations on the bottom have been made by SCUBA diving, photographs taken at 25 stations, and records of the bottom morphology made with a small depth recorder. Studies reveal a complex 
pattern of muds and pooly sorter till-like deposits which cover the Arm. Paleozoic rocks (Halifax Slate and granite) crop out and are swept clear of sediment by bottom currents. Current meter data is being obtained to interpret these bottom current movements.

The Northwest Arm was deepened and given its U-shape during the Pleistocene Epoch. Ice was also responsible for filling this depression with till debris. These deposits have been reworded during the Holocene rise in sea level as well as by modern tidal currents. In areas of higher energy, near the margins of the fjord and in the central restricted portion (only 150 metres wide near the Dingle), currents have winnowed out fines leaving a cobble-boulder lag deposit. A thin layer of mud covers the bottom in quieter areas. Cores and sub-bottom profile records indicate that this mud is a thin veneer generally less than 1 metre thick, and that it covers till-like deposits which in turn overlie the Paleozoic bedrock.

Foraminiferal distribution and ecology in the Arm are presently under study by DR. FRANCO MEDIOLI of Dalhousie University. This investigation will be completed this summer and is to be reported upon at the 1967 meeting of the NORTHEASTERN SECTION OF THE GEOLOGICAL SOCIETY OF AMERICA.

Colour of sediments on the Atlantic Continental Margin - A systematic examination of the regional colour distribution of the upper sediment layer on the Atlantic Continental Margin between Nova Scotia and Key West, Florida has just been completed. This project was sponsored by the WOODS HOLE OCEANOGRAPHIC INSTITUTION and U.S. GEOLOGICAL SURVEY as part of their Program for the Atlantic Continental Margin (K.O. EMERY, Maritime Sediments 2-ii 55-68, Apri1 1966)

The major break in colour patterns on the shelf takes place near Cape Hatteras. Browns, dark greens and yellows dominate the shelf north of Cape Hatteras; to the south, olive, grey and yellow shades predominate. Many of the colour patterns on the shelf proper are more closely related to Pleistocene and Holocene sedimentary events than to modern dispersal patterns. Marked examples of relict patterns include areas such as Georges and Browns Banks which were exposed during lower stands of sea leve1. Discontinuous but linear belts of yellow sediments on the outer shelf and along the shelf break south of Cape Hatteras are probably also related to strand-line features formed during the Pleistocene low stands of sea level, and during the transgressive advance of the Holocene sea.

Colour patterns on the continental slope and rise and on the Blake Plateau, unlike those on the shelf, are aligned in linear belts which trend parallel or subparallel to the shelf break. Major trends vary regularly with depth, i.e., varying from olive and green to light grey and pale yellowish brown to brown and yellow shades between the upper slope and rise. This transition is probably related to the oxidationreduction potential of the environment, the rate of deposition, the rate of decomposition of organic matter deposited with the sediment, and bacterial activity. Isolated pods of colour on the slope and rise are due to the slumping of sediment masses downslope, and to the exposure of pre-Holocene outcrops. Reworking of red Pleistocene till masses, which 
were once exposed on the Scotian Shelf during the glacial epoch, may have taken place during the Holocene rise in sea level: this may explain why brown and reddish-brown sediments are found at progressively shallower depths on the rise and slope off the Gulf of Maine and Nova Scotia.

This study demonstrates how colour, an oft-neglected petrographic property, can independently of the more commonly studied parameters highlight areas of relict and modern deposition and bring to light something of the origin of the sedimentary cover of the continental margin.

Sedimentary structures studied by infrared photography - A simple, rapid, and inexpensive method for studying the structures in unconsolidated sediments as well as in sedimentary rocks has been developed in conjunction with DR. DONALD C. RHOADS, YALE UNIVERSITY. This method involves photographing thin slabs of sediments or rocks with infrared film which is sensitive to differences in texture, heavy minerals, and organic matter. The method is explained in a joint paper to appear this fall in the Journal of Sedimentary Petrology. A second joint paper describing the application of infrared photography to so-called "structureless" dune sands is presently in press in the Bulletin of the American Association of Petroleum Geologists.

\section{ANCIENT SEDIMENTS}

Precambrian rocks of the Caledonia Mountains, Southeastern N.B.

Mapping of the Precambrian metamorphic complex at the east end of the Caledonia Mountains, in Westmoreland and Albert Counties, New Brunswick, is being done by DR. DOUGLAS $\mathrm{H}$. WILLIAMSON of LAURENTIAN UNIVERSITY, Sudbury, Ontario. Dr. Williamson, until this summer Head of the Department of Geology at MOUNT ALLISON UNIVERSITY, Sackville, New Brunswick, has been working in the area for more than four years, and has mapped a large portion of the eastern end of the complex; his area borders on one side the Point Wolfe geological map produced by E.M. KINDLE a few years ago.

Although this summer's work has been restricted by illness and the labour of changing his habitat, Dr. Williamson has put in several weeks' mapping; he intends to continue this work in future seasons.

Cambrian Paleoecology and Environments, Paleozoic Fossil Fish

A study of the Cambrian rocks of the Atlantic Provinces is currently being conducted by DR. HUGO R. GREINER of the UNIVERSITY OF NEW BRUNSWICK, from the standpoints of paleoecology and sedimentary environments. Synthesis of earlier work, mainly by WALCOTT, MATTHEW, HOWELL and HUTCHINSON, as well as comparison of the various Atlantic faunal outcrop areas, is also being attempted. This work is being supported by a grant from the NATIONAL RESEARCH COUNCIL OF CANADA.

Additiona11y, Dr. Greiner is continuing work on a project of several years' standing, dealing with fossil fish and fish-zones of the Maritime 
Provinces. Efforts so far have mainly been directed at the palaeoniscids of the Albert Formation (Carboniferous), which has yielded a fairly large collection. Fragmentary material from the Silurian rocks at Nerepis, north of Saint John, has aiso been obtained. Support for this work comes from a GEOLOGICAL SURVEY OF CANADA grant.

Ordovician and Silurian Geosynclinal Sequences, Saint John River Valley, N. B.

A re-survey of the Ordovician and Silurian greywacke sequences, and a study of their relations with the Pokiok igneous complex, is being undertaken this summer by DR. ALAN J. GORDON of the UNIVERSITY OF NEW BRUNSWICK IN SAINT JOHN. Sponsored by the NEW BRUNSWICK DEPARTMENT OF NATURAI RESOURCES, Dr. Gordon is working in the area of the Saint John River valley due to be flooded by the new hydro-electric development under way at Mactaquac, 14 miles west of Fredericton.

This work will form the basis for a study of Lower Paleozoic paleogeographical conditions in central New Brunswick. It is hoped to integrate structural studies, petrographic analysis and current directions suggested by sole markings. The problem is complicated by the lack of marker horizons although a number of previously unreported silurian fossil localities have recently been found.

\section{Fossil Spores from the Albert Formation (Carboniferous)}

A study of fossil spores has recently been commenced by DR. C.P. VARMA, who is an N.R.C. Postdoctoral Fellow at the UNIVERSITY OF NEW BRUNSWICK. During the last few months several trips have been made to outcrops of the Albert shales in Albert County, New Brunswick, to collect suitable material for analysis. A few of the finer-grained shales have started to yield spores, though much work is foreseen before useful results may be obtained. Dr. Varma has come to U.N.B. from the OIL AND NATURAL GAS COMMISSION, Dehra Dun, India.

Carboniferous Sedimentology near Joggins, N.S.

Carboniferous rocks in the famous coast section south of Joggins, Nova Scotia, are being investigated by JOHN $\mathrm{H}$. WAY, Jr., of the UNIVERSITY OF PENNSYLVANIA. The project, for a master's thesis, is being supported by a grant from the NOVA SCOTIA RESEARCH FOUNDATION and is being supervised by DR. GEORGE deVRIES KLEIN.

\section{GEOCHEMISTRY}

Groundwater Chemistry in Triassic Rocks, Grand Manan, N. B.

Flat-lying volcanic rocks of Triassic age form much of Grand Manan Island, N.B., overlying red sandstones and siltstones of similar age. A study of the chemistry of the groundwater in both types of rock, with particular emphasis on the chemical changes that occur at the volcanicsediment interface, is currently being undertaken by GEORGE E. PAJARI of 
the UNIVERSITY OF NEW BRUNSWICK in collaboration with DR. LOWELL E. TREMBATH and undergraduate assistants in the Department of Geology.

The purpose of the study is to define the reactions that take place between the groundwater and the rocks as the water passes the interface. Sampling began in 1964, and subsequently in 1965 and 1966; the work should be completed in 1967 . 